\title{
THE DOMINANCE OF TERRORISM: ASPECTS OF THE SOCIO-POLITICAL CHALLENGES IN POST-INDEPENDENCE WEST AFRICA: NIGERIA, BURKINA FASO AND MALI
}

\author{
Osiomheyalo 0. Idaewor ${ }^{1}$
}

\section{Introduction}

The West African countries, namely, Nigeria, Burkina Faso and Mali, all gained independence in 1960 . Since the attainment of independence, these countries have continued to witness peculiar socio-political and economic challenges. These include the contemporary menace of terrorist groups such as the Boko Haram, ISWAP (Islamic State West Africa Province), and their local and international affiliates. These challenges had been precipitated by both local and external socio-political and economic dynamics in the sub-region. Apparently, the challenge of terrorism has intensified in a way that it has overshadowed and compounded existing challenges in West Africa in the contemporary period.

Terrorism is defined in this paper as the deliberate commission of an act of violence by non-state actors, whether individuals or groups, in order to create public fear and psychological disturbance, through the suffering of the victims, in the furtherance of a political, economic, religious or social agenda of a specific geographical region.

These terrorists, who could otherwise be regarded as Islamic fundamentalists, seem determined to establish an Islamic or quasi-Islamic state-style caliphate across the sub-region. Affiliate terrorist groups in the sub-region include the Islamic State (ISIS), al-Qaeda in the Islamic Maghreb (AQIM), National Movement for the Liberation of Azawad (MNLA), the Tuareg jihadists,

I Department of History and Strategic Studies, University of Lagos. Lagos, Nigeria. E-mail: osiomheyalo@gmail.com 
among other emerging jihadist groups. Apparently, the efforts of interventionist initiatives such as the G5-Sahel, MNJTF, MINUSMA, ECOWAS, and others, have not been able to eradicate the deadly attacks by terrorists in West Africa.

It is imperative to note that there are both national and international concerns as to whether militias, gangs and sects, or those who metamorphosed into having violent orientations, are terrorists. These include among others, the Maitatsine and the Shiite sects in Nigeria, the Tuareg jihadists in Mali, and the violent Fulani herdsmen across the sub-region. Aside the defunct violent Maitatsine sect in Kano, northern Nigeria, which invariably claimed thousands of lives and properties during the I980s, and which was characterised by mass looting maiming, assaulting women and killing of citizens (Adegun 20I7), the other groups are currently believed to have links with Boko Haram, ISWAP and ISIS. To this end, this paper is rather focusing on terrorism, as regards the well-known Boko Haram and ISWAP, including their affiliates. The choice of the aforementioned countries, which to some extent cut-across the loose Sahel region of West Africa, is reflective of the current terrorist activities there (Chergui 20I9; Pujol-Mazzini 20I8).

Terrorist activities have been further intensified in the Sahel region after chaos engulfed Libya as a result of the overthrow of long-time dictator, Muammar Gaddafi, in 20II. Terrorist activities include, inter alia, suicide bombing, mass killings, raping, maiming, arsons and kidnapping. These deadly activities and the general feeling of psychological, socio-political and economic insecurity of lives and properties are, however, not limited to the Sahel parts alone, but the length and breadth of the concerned countries as a whole. In fact, the heinous crimes committed by Boko Haram, ISWAP and their affiliates, transcend the national boundaries of the aforementioned West African states. This has taken centre stage in the current global security and strategic discourse (Chergui 2019; Gberie 2016).

The deadly terrorist activities of Boko Haram since 2009 (especially in the northeastern part of Nigeria and the Chad Basin), ISWAP, and their affiliates, has succeeded in intensifying and compounding the hitherto socio-political and economic challenges of contemporary Nigeria, (colonized by Britain), Mali and Burkina Faso, (both colonized by France). Succinctly, these challenges include bad governance, ethnic conflicts, political fragility, kidnapping and poor economy, to mention a few (Blake 20I9; Pujol-Mazzini 20I8; Arieff 20I8).

In qualitative terms, the West African sub-region currently harbours some of the world's poorest countries such as Mali, Guinea Bissau and Burkina Faso, among others. This is in spite of the contemporary phenomenon of globalization, regional integration and the "colonial hegemonic 
connections". Imperatively, varying factors have influenced the socio-political and economic performance of respective countries in West Africa over the decades. These included, inter alia, human and material resources, development strategies, political conditions and sources of finance. Therefore, it is not an easy venture to make generalizations about the socio-economic development of West Africa during the post-colonial period. It is pertinent, therefore, to emphasize that it is not the intention of this paper to enumerate, in quantitative and statistical terms, the socio-economic indices of the respective West African states.

It is worth noting that some works on the socio-political economy of West Africa had already set a stage for the analysis of the contemporary developments. These works (Ake I983; Rodney I972; Lawal I997; Onyekpe I997), discuss, inter alia, the socio-political and economic dynamics and relations of the Developed and Underdeveloped nations, prior to the twentieth century. They identified some of the root causes of the continued post-colonial underdevelopment of Africa. However, the issue of insurgency or terrorism, and its aggravation of the existing socio-political and economic challenges in West Africa was not emphasized in the aforementioned works.

The work by Kuerschner (20I3) provides an analysis of the dynamics of conflicts in West Africa, focusing on the Civil Wars in Liberia and Sierra Leone during the late twentieth century. He noted that economic and socio-political factors were crucial in the conflicts. However, the restriction of the study to those two countries only captures a minor aspect of the socio-political and economic challenges inherent in West Africa. The present study intends to expand the scope by underscoring how the outbreak and intensification of terrorism in the contemporary period had strong linkages with the socio-political and economic contexts in the sub-region since the late twentieth century.

Equally germane are the separate works by the Africa Development Bank (ADB), titled, West Africa Economic Outlook (20I8), and that edited by Ogunremi and Faluyi (I996). These works provide a rather comprehensive analysis of the economic dynamics of the sub-region. The works underscore the extent to which the dwindling economy of West Africa influenced the indices for underdevelopment, among others. However, their inability to emphasize some of the crucial socio-political factors which directly impeded the economy of the sub-region, coupled with the dynamics of terrorism, creates a gap in our understanding of the historical development of the sub-region. However, this present study intends to fill this major gap.

Placed in perspectives, this paper gives an overview of the linkage between the post-colonial and post-independence periods, thereby under- 
scoring the contemporary intensification of terrorism. It further examines the contributions of the UN, ECOWAS, MINUSMA, G5-Sahel and other interventionists' initiatives towards the development of the sub-region. It concludes by proffering some prospects for development.

\section{Challenges since independence: an overview}

The colonial authorities, during the late nineteenth and early twentieth centuries, asserted their political and socio-economic hegemony in the sub-region. Some scholars consider that in the process, the colonial masters discovered, expropriated and exploited the potential human, mineral and natural resources of the various territories in Africa. Hence, the underdevelopment of Africa (Onyekpe I997; Claude Ake; I983; Rodney I972). Meanwhile, others scholars have opined that although colonialism had its own demerits, it had more positive than negative impacts on Africa (Gann and Duignan I967). In the ongoing analysis, it is imperative to note that Fieldhouse (1999) and Ferguson (2003) have expressed their reservations about the direct impact of colonialism on Africa. These authors maintained that although the seeming negative impact of colonialism was underdevelopment, it was however minimal and not deliberate.

Many of the African states continued to maintain links with their former colonial masters, such as the British and French, especially through diplomatic ties and economic interaction. The activities of some foreign multinational companies, such as the United African Company (UAC) and John Holts could be linked in this regards. Apparently, these companies were technically European agents, noted for their massive economic exploitation of African resources. Nevertheless, social amenities, such as schools, road transportation, railways and telegraphs, among other infrastructures, were ostensibly set in place by the Europeans in each colonial territory, albeit in varying degrees. In the area of provision of conventional health care service, the colonial authorities established clinics, hospitals and dispensaries in the sub-region, such as Lagos (Nigeria), Accra (Ghana) and Freetown (Sierra Leone). However, to what extent these services performed since the attainment of independence remains to be determined as the sub-region still lacks significant and efficient basic health care system.

The twentieth century was a landmark in the socio-political, cultural, diplomatic and economic history and historiography of West Africa. Particularly, many countries in the sub-region, except Liberia, got their indepen- 
dence from the former colonial (European) masters, such as Britain, France, Belgium and Portugal. Interestingly, some parts of the sub-region, including Nigeria, Mali and Senegal, among others, had already been influenced by the Islamic civilization centuries prior to the advent of the Europeans. However, the latter's hegemony was strong enough to significantly transform the hitherto pre-colonial arrangement to the conventional status. Some scholars such as Rodney (1972) and Onyekpe (1997), among others, have opined that it was because of the contradictions exhibited by the colonial administration towards the Africans that nevertheless paved the way for some of the socio-political and economic challenges witnessed in the contemporary period.

Since the political independence of the countries in focus was collectively achieved, economic and socio-political challenges gradually gained grounds. This situation, among other factors, could partly be attributed to the divisions, which the Western powers, deliberately or otherwise, imposed on the continent, such that artificial demarcations of polities were created without the consent of the local Africans (Watson I980, 307). In clear terms, the sub-region consequently witnessed series of political upheavals and intrigues during the post-I96os. Obviously, these challenges frustrated genuine regional cooperative linkages (Olagbaju and Falola, 226-227), among other socio-economic and foreign contexts in West Africa.

Furthermore, since the attainment of independence, countries in the sub-region continued to suffer from incessant balance of payments deficit (Lawal I997, 210). The importation of capital and consumer goods, on a massive basis, to finance internal development projects have been largely responsible for this challenge. Thus, respective countries had to enact monetary, fiscal and exchange policies to maintain external equilibrium and conserve foreign exchange reserves.

The inability or lack of access to external financial markets stands as another problem encountered by developing countries (including those of West Africa). All loans that the developing countries were able to obtain end up accumulating huge debts and interest charges. Hence, external capital have been used to cover interest payment rather than investment over the years. The latest economic estimates show that West Africa battles with a high level of poverty. With the informal workers (estimated to be about 80 percent overall in Africa), receiving wages below the poverty line. The estimates therefore show that about 43 percent of the collective population in the sub-region live below the international \$I.90 per day poverty line (ADB 20I8, 4).

Based on the colonial experience, West African countries still maintain trade and monetary ties with their former colonial administrators espe- 
cially in Europe, and other industrial countries, such as the USA, Japan and Canada. These foreign powers however have different ideological orientations. Apparently, trade imbalance between West African countries constitutes a major barrier to "real" economic integration and development (Olagbaju and Falola, 234-235; Lawal I997, 210). This is in spite of the establishment of ECOWAS in I975. The ECOWAS was aimed at promoting the economic integration, as well as maintaining the collective security of the sub-region. However, with its I 6 member countries, ECOWAS is still faced with myriads of socio-political and economic challenges. In essence, the sub-region still lacks "real" economic integration, among other challenges such as high mortality, unemployment, inadequate health care systems, porous borders, environmental degradation, corruption, poor governance, religious and ethnic intolerance, and more recently, terrorism. All these challenges with no doubt encourage socio-political and economic underdevelopment.

More importantly, the aforementioned colonial and foreign powers have since been aware of the dangers that might befall them if ECOWAS were to be united in their quest for socio-political and economic greatness. Aside this, the formation of yet another union within ECOWAS, the CEAO, (the French speaking West African Economic Community) might likely stand as an obstacle to the overall aim and objective of ECOWAS (Olagbaju and Falola, 226-227).

Regrettably, with the high availability of human, mineral and natural resources, such as, crude oil, gas, energy, lead/zinc, ore reserves, wild life, land, waterways, rubber, cocoa, and gold, amongst others, the sub-region, however, remains one of the most underdeveloped in the world. Nigeria for example is the most populous nation in West Africa, with over 200 million people (Aworinde 20I9). It is also one of the largest producers of crude oil in the world and a very large economy in Africa. Yet, socio-political and economic challenges have continued to fester. In spite of the Federal Government of Nigeria's efforts at improving these conditions, there is, for example, marked underfunding of sectors of the economy, including education and health.

Generally, there is a high mortality rate in spite of the availability of hospitals, doctors and equipments in West Africa. In this regard, efforts to remedy the inadequacies in health care especially during the late twentieth century included the Bamako Initiative. Concisely, much was not achieved with this Initiative, as respective countries in the sub-region continued to experience inadequacies in the provision of health care services to their citizens (McPake et al I993, I383-95; Odejide and Morakinyo 2003, I64-65). Can one then compare the workability and accessibility of these services in 
post-independence West Africa's to what obtains in Developed Societies, such as Europe or the US? Aside these, the perception of the citizens towards their various governments as regards administrative transparency, sincerity of purpose and committed developmental policies pose another major challenge to West Africa's development.

The deliberate neglect or abandonment of public and private duties, illegal acquisition of public resources, nepotism, alongside the insincerity of purpose, among others, all account for the endemic corruption prevalent in contemporary West Africa. Relatedly, the level of financial corruption and administrative recklessness exhibited by many government officials in West Africa, and the inability to strengthen anti-corruption institutions, such as the Independent Corrupt Practices Commission (ICPC) and Economic and Financial Crimes Commission (EFCC), both in Nigeria, contribute to the contemporary challenges. In addition, the inability of the Police to prosecute some of the "alleged" corrupt officials successfully further compounds the inherent challenges in West Africa. It is important to note as well that while some of the looted funds by these purportedly corrupt officials are hidden locally, the majority are deposited in foreign financial institutions.

Ironically, the mere availability of modern socio-economic infrastructures such as internet facilities, airports, electronic media, mechanized agriculture, modernized transport system, schools, among other conventional services, do not in any way translate to real national development. The workability of these services, and their accessibility to majority of lives, as well as serving the essence of purpose, productively, positively and purposeful, remain lacking. These, among other factors, hinder the holistic growth and development of modern West Africa.

\section{Terrorism: the contemporary challenge}

An assessment of the socio-political and economic challenges earlier discussed contributed immensely to the fecundity, spread and intensification of terrorist's activities in the areas of study (Pujol-Mazzini 2018; Blake 2019). Without stereotyping, these challenges, which include porous borders along the Sahel region, poor governance, inadequate infrastructure, political instability, ethnic rivalry, lack of political will to combat insurgency, sabotage, inadequate training and funding of security agents (Chergui 2019), ethno-religious suspicion, and youth unemployment, among others, have helped significantly to the rapid spread of terrorism across the sub-region. 
A typical example is the postulation by Blake (20I9) that the high level of political instability and poverty have been largely responsible for the intensification of terrorism in the sub-region, citing the example of contemporary Guinea Bissau. This is similar to what obtains in other parts of West Africa, such as Burkina Faso, Mali and Nigeria. In some cases, the teeming unemployed or poor youths in these countries are easily enticed with money to be recruited into terrorist organizations such as, Boko Haram and its affiliates. Thus, the failure of leadership, weak prosecutor and enforcement institutions, among other socio-political and economic contexts, cannot be exonerated from the current spread of terrorism in the sub-region.

Respective West African countries had experienced a series of socio-political turmoil since gaining independence. These ranged from the various military coups d'états, shortly after independence, to Civil Wars, including regional and ethno-religious rivalries, among others. Seemingly, Islamic terrorist groups, such as the Boko Haram and ISWAP, both having links with ISIS and al-Qaeda and others, have begun to turn their attention to West African countries notably, Nigeria, Mali, Burkina Faso and even Senegal, one of West Africa's most stable nations, especially after the colonial period (Pujol-Mazzini 2018).

These terrorists are jihadists, with extremist Islamic or quasi-Islamic orientation. At least in Africa, these terrorist groups are determined to establish a massive Islamic state-style caliphate (Gberie 20I6), having direct links with the Middle East, the Maghreb, the Horn of Africa, down the sub-Saharan territory, invariably terrorizing inhabitants within the regions. Terrorists could also claim to be dissatisfied with the existing socio-political order. For instance, the designation Boko Haram simply means "western or non-Islamic education is a sin" (Kelly 20I9). Thus, in pursuance of this anti-Western, unconventional ideology, this group, like others, resort to attacking any conventional entity or arrangement found within their targeted region. The group therefore resort to unconventional warfare, kidnapping, suicide bombing, and the mass killing of unsuspecting citizens in places of worship, markets, military barracks and schools, among other public and private places.

Poverty stands as a crucial factor in the spread of terrorism. Burkina Faso, for instance, is ranked amongst the poorest countries in Africa, with about half of the population living below the internationally approved poverty line of \$I.90 per day (ADB 4, Blake 20I9). This is worsened by political instability, kidnapping and killings. These conditions undoubtedly contributed to the infiltration and spread of international terrorist groups, such as ISWAP and their affiliates within and outside the country. Since the regime 
of the former President, Blaise Campaore, was toppled in 2014 by a popular revolution, Burkina Faso has experienced over 200 attacks by terrorist groups having international links with al-Qaeda and IS. The rise in the number of attacks has been attributed to the declining security apparatus and the general political instability in the country. Invariably, internal political instability served as a catalyst for the rapid influx of insurgents. Thus, the consequence of this has been the perpetration of perhaps some of the most vicious attacks in the history of Burkina Faso. A typical example in this regards is the January 2016 attack on the Splendid Hotel in Ouagadougou, which killed about 30 people (Blake 20I9; Gberie 20I6).

In Mali, ethnic violence and political instability since the I960s have contributed in no small measure to the rather unhindered activities of the AQIM, al-Qaeda, MNLA, ISWAP and Boko Haram affiliates up to the contemporary period. Evidently, there is a worsening violence ongoing largely between Muslim jihadists and Malians. This has further led to inter-communal or inter-ethnic violence. Aside the violent attacks by extremists, Mali also currently suffers the challenge of separatists, as the Tuareg ethnic group in the north are attempting to seek political autonomy. Although former President Lt. Moussa Traore's regime repressed the Tuareg rebellion, armed clashes as well as jihadists' attacks continued despite the peace accord in January, I99I (Nossiter 2012). A notable deadly attack by terrorists in Mali took place in November 2015, when some affiliated terrorists groups, who claimed to be AQIM, attacked the Radisson Blu Hotel in Bamako, killing 22 people, including two attackers (Gberie 20I6). These challenges, as well as the poor environmental conditions, such as recurrent drought, high population growth, decrepit infrastructure, among others, have all continued to undermine the development process of contemporary Mali (Arieff 20I8).

Furthermore, the Boko Haram insurgency in parts of Nigeria and the Chad Basin, is among the challenges facing contemporary West Africa. With the violent attacks meted by terrorists on innocent citizens, public and private properties, among others, the socio-political and economic landscape of the countries affected are thereby seriously distorted without any meaningful socio-economic development. Coupled with this is the psychological trauma experienced by both the young and old who are caught in the web of these violent guerilla or surprise attacks by terrorists. Meanwhile, the unwarranted violence, as evident in north eastern Nigeria and the Chad Basin, have resulted in the killing of over 27,000 people. It has also affected about 2 million others who are currently displaced and in dire need of humanitarian services (WHO 20I9; Kelly 20I9). 
A latest development indicates that ISWAP is strongly entrenching its hold in Nigeria and parts of the Chad Basin. This terrorist group has been able to influence some of the local population who have accepted to abide by their rule and ideology. In this regard, those locals who have abided by the rather favourable governance style of ISWAP could carry out socio-economic activities unhindered. Accordingly, ISWAP has been able to gain the support of the locals such that more terrorists are easily recruited from the teeming youth population there (ISSAT 20I9).

Apparently, the Boko Haram and ISWAP terrorists groups are sponsored by foreigners and other affiliates. Assertively, there are also other internal "unidentified" collaborators who are determined to sabotage the efforts of government in the war against terrorism (Umeh 20I9). There are also indications that there exists some socio-economic motives behind terrorist attacks. In the northern part of Nigeria, Zamfara state to be precise, there are ongoing violent activities of "bandits," known for terrorizing and killing innocent citizens through the use of weapons, such as AK-47, machetes and dynamites, among others, to loot, expropriate, murder, rape and maim. Apparently, socio-economic and security challenges have considerably increased, leaving thousands of displaced inhabitants in need of humanitarian assistance (Sahara Reporters 20I9).

Imperatively these socio-political crises have a direct negative consequence on the lives and properties of the affected territories. This invariably raises the issue of provision and enforcement of adequate health care services for victims of terrorist attacks and other forms of violence. Although the Geneva Convention prohibits attacks on health care facilities during wars, such incidences have continued unabated in West Africa as a consequence of terrorism and ethnic violence. In the northern region of Nigeria and the Chad Basin, Mali and Burkina Faso, the provision of health care service is critically hampered by the insecurity posed by Boko Haram and ISWAP terrorists. In 20I6, two-thirds of the 743 health care facilities in Nigeria, for instance, were completely damaged or destroyed by terrorist attacks, thereby leaving a large number of people unable to access humanitarian services (WHO 20I7).

\section{Interventions and foreign contributions}

The international community has contributed immensely to the fight against terrorism and other forms of political violence in the sub-region. The contribution of the UN in this regard cannot be overemphasised. 
In September 2006, the UN General Assembly adopted the United Nations Global Counter-Terrorism Strategy. This was meant to enhance national, regional and international efforts to counter terrorism through a common strategic and operational approach. By extension, the strategy is aimed at taking practical steps, individually and collectively, to prevent and combat terrorism globally (UN 2006). Prior to 2006, the activities of ECOMOG (ECOWAS Monitoring Group), and UN peacekeeping missions in Liberia and Sierra Leone during the Civil Wars in both countries are also worthy of note (Kuerschner 2013). Other efforts at waging war on terrorism and enhancing regional peace and security in West Africa have been carried out by the US and other counterterrorism initiatives.

In efforts at curtailing and countering terrorism in the sub-region, the US recently pledged the sum of $\$ 60$ million to build a new African counterterrorism force. This is in addition to the presence of a regional United Nations Force in West Africa. This Force consists of American and European troops (Pujol-Mazzini 20I8). The UN has also continued to raise awareness towards the need to support humanitarian efforts in the sub-region. In a recent development, for instance, the UN office for the Coordination of Humanitarian Affairs estimates that about I.2 million people are currently in need of special humanitarian assistance because of ethno-political conflicts and terrorist attacks in Burkina Faso (Blake 2019).

Other ongoing interventionist effort by the US government in West Africa is the PSI (Pan Sahel Initiative), which operated between 2002 and 2004. It subsequently paved the way for the TSCTI (Trans-Saharan Counterterrorism Initiative) in 2005. It was incorporated into the United States Africa Command in 2008. Notably, the TSCTI was an expanded version of the PSI with similar aims and objectives. Whereas the PSI was made up of partner countries including Chad, Mali, Niger and Mauritania, TSCTI partner nations currently include Nigeria, Burkina Faso, Mali, Libya, Morocco, Mauritania, Chad and Senegal. Primarily, TSCTI is intended to counter terrorism in the sub-region and assist respective governments to control and protect their territories against the incursion of terrorists (Miles 2005).

Relatedly, the US has since 2015, continued to support the issue of food security and agricultural development in the conflict prone northeastern part of Nigeria (FAO 2I06). According to recent reports, the US has spent, in the way of intervention, about $\${ }_{1} 6_{5}$ million to support farmers and displaced people in the country to restore food security, tackle severe hunger and malnutrition, as well as develop the overall agricultural sector. This intervention, through an initiative known as the Feed the Future Global 
Food Security Strategy (Nigeria Country Plan), also focuses on improving conditions in northeastern Nigeria where terrorism has greatly disrupted agriculture, among other socio-economic ramifications (Agric Base 2019).

In Mali, for instance, foreign troops from Europe (particularly the former colonial masters - the French), have contributed towards the attainment of peace by countering terrorism. Similarly, MINUSMA has been charged with the task of protecting civilians and supporting the peace process. Equally important is the European Union's (EU) multi-year program to train and restructure the Malian military. In 20I7, a regional force, called the G5-Sahel, which is made up of five neighboring countries including Mali, Mauritania, Niger, Burkina Faso and Chad launched a joint force to counter security threats in border regions. The initiative has so far received donor backing, but has conducted few operations to date. However, the G5-Sahel, with their operational headquarters in central Mali, is currently faced with some challenges as terrorist attacks continue to linger (Arieff 20I8). Inadequate funding of the $\mathrm{G}_{5}$-Sahel force, as well as others, is largely responsible for some of the challenges in the sub-region.

In the provision of health care and humanitarian services for victims of terrorist attacks including other forms of conflicts in contemporary West Africa, the World Health Organization (WHO) has continued to play a major role. It should be noted that the WHO is responsible for coordinating the overall health care services, alongside interfacing with security mechanisms in conflicts zones globally. It is also responsible for supporting the national health authorities of respective countries in the international system to strengthen their core responsibilities. Thus, in northeastern Nigeria for instance, WHO has been able to support the Borno State government to establish an all-hazard Emergency Operation Centre. However, in 20I7, only a third of requested funding was received by WHO and their health partners, thus, making the provision of humanitarian and other health care services inadequate for victims and survivors of terrorist attacks among other forms of conflicts in the sub-region. Generally, since WHO's aim is to address global health threats, it has so far been able to support over six million refugees and internally-displaced persons in contemporary Africa (WHO 20I7).

\section{Conclusion}

Apparently, terrorism was most prominent among the challenges in the areas of study. From the qualitative historical point of view, the contradictions inherent in the internal and external dynamics of the colonial adminis- 
tration were invariably responsible for the post-independence socio-political and economic challenges faced in the sub-region. Aside the challenges since the I960s, the 2000 s were marked with incessant terrorist attacks in the areas of study (Chergui 20I9). Certainly, the establishment of the UN Global Counter-Terrorism Strategy in 2006, played a crucial role in the counter terrorism crusade in the sub-region and other parts of Africa (Miles 2005). However, the extent to which this strategy was adopted and domesticated in the countries under consideration remains debatable, as incessant deadly terrorist acts continued to recur.

Abreast of the global phenomenon of terrorism in scholarly discourse, it is pertinent to note that these challenges are not limited to West Africa alone. In contemporary East, Central and North Africa, countries like Kenya, Somalia, Sudan, Democratic Republic of Congo and Tunisia, and others, are faced with serious local, national, regional and socio-political challenges. These challenges, which cut-across the socio-political and economic milieus, are further worsened by the deadly activities of terrorists, such as al-Shabaab in the East, al-Qaeda and extremists jihadists in the North and the Allied Forces in Central and East Africa.

Acknowledging the roles played by the UN, US, EU, ECOWAS, G5-Sahel, MINUSMA and TSCTI, among others, the aforementioned West African countries however still rank among the poorest in the comity of nations. Little wonder ISWAP is currently gaining support from civilians in parts of their conquered territories in the northeast of Nigeria and the Chad Basin. The seeming favourable governance structure of ISWAP in these territories has further encouraged the easy recruitment of youths into the terrorist group (ISSAT 20I9).

It is for that reason, instructive to advocate for the need to address the internal socio-political and economic challenges inherent in these West African states so that terrorism will no longer have "a fertile ground to grow." Therefore, respective governments in the sub-region should exhibit the necessary sincerity, political will and commitment to, as a matter of urgency, put the socio-political and economic environment on the path of growth and development. In this regard, employment and adequate educational opportunities should be provided for the teeming youth population in the area of study. Good governance and the "real" tenets of democracy should be learnt, encouraged and practiced. Political leaders in these countries should endeavor to eschew corruption, nepotism, religious intolerance, ethnic rivalry and partisanship and so on, and focus on the overall development of their countries without prejudice or ethno-religious bias. 
The economy should be managed by seasoned professionals, with clearly defined national ideologies for positive nation building, such that would attract both local and foreign investors. The overall security architecture should be well funded by the relevant authorities. Respective internal borders in the sub-region should be well manned by patriotic security officials. The proliferation of firearms across borders should also be checked. In this connection, the military personnels, and other security agents should be well trained, equipped and well remunerated in the course of their service to protect lives and properties within the respective countries. By so doing, the contemporary terrorist activities and their rampancy in the sub-region would be curtailed.

In the area of sub-regional cooperation, integration and development, this paper recommends that:

I. The resolution of the UN's Global Counter-Terrorism Strategy of 2006 should be strictly adhered to and adopted, individually and collectively, by the respective countries in the sub-region. This rather comprehensive resolution generally provides for collaborative, combative, preventive and protective actions against terrorism in the sub-region as well as globally.

2. The mission statement, aims and objectives of ECOWAS must be strictly adhered to and actively enforced without ethnic, socio-political or diplomatic prejudice. ECOWAS member countries and institutions, not minding their former colonial affiliations, should endeavor to encourage mutual inter-state trade and freedom, efficient management of resources, provision of adequate transportation infrastructure, provision of qualitative education and employment opportunities for the numerous youths. They should also enforce the collective security of member states through the necessary organs and institutions of government. By so doing, socio-economic challenges such as poverty, unemployment and trade restrictions etc., would be a thing of the past. Respective governments within ECOWAS should take central and active roles in this regard.

3. Against the background that ECOWAS currently allows citizens of member states to travel around the sub-region without visas, as well as the daunting challenges of poor border control, as human and arms trafficking, the military intelligence should, as a matter of urgency, be employed such that suspected terrorist individuals or groups are monitored and followed as soon as they 
enter the respective countries across West Africa. Relatedly, there is need to strengthen cordial diplomatic ties, among the states of the sub-region. By so doing, terrorism could be curtailed from spreading across borders.

4. Perhaps, through the ECOWAS institution or any of the sub-regional counter terrorism Initiatives, government officials and terrorists in Mali, Nigeria and Burkina Faso should engage more on workable dialogue and amnesty programmes. In this connection, local terrorists should also be curtailed by national law enforcement agencies before their escalation across borders. A typical example is the Boko Haram insurgency. This group was initially thought to be mere militants in the northeastern part of Nigeria, and therefore not adequately given the necessary military attention before it transformed into a full-blown international terrorist group which spread to other countries in West Africa.

5. The WHO, as well as their partners in the respective countries in West Africa should endeavor to establish a workable system for collecting data on attacks by terrorists on health workers, health facilities and patients, as this will help in the overall assessment, control and prevention of health hazards, and the provision of health and security for all. In this regard, war crimes committed by terrorists as a result should be judiciously and adequately addressed, with a sense of purpose, by the respective national judicial systems across West Africa, the ECOWAS Court and/ or, the International Criminal Court.

6. Without prejudice to foreign colonial or diplomatic affiliations, ECOWAS member states should make regional security their watchword. These countries should not fund or conspire with terrorists groups, as the repercussion for this obnoxious act could spell doom for not only the conspirer, but also the sub-region as a whole. This is because terrorist groups, sometimes, act irrationally, and deviate from their specific goals to inflicting untold calamity on any target through suicide bombing, kidnapping and attacking soft targets, such as public and private entities.

7. Counter terrorism Initiatives in the sub-region, such as the G5-Sahel, MNJTF, TSCTI and others, should exercise the necessary sincerity of purpose in their anti-terrorism endeavors. They should equally be well funded by donor countries without any ulterior motives or conspiratorial tendencies with terrorists. 


\section{References}

Adegun, Aanu. 20I7. "Maitatsine: Story of Nigeria's Bloody religious Terror of the 8os- Grandfather of Boko Haram." Legit. https://www.legit. ng/amp/IIOI39I-maitatsine-story-nigerias-bloody-religious-terror-8os-grandmother-boko-haram.html

Africa Development Bank. 20I8. West Africa Economic Outlook.

Agric Base. 20I9. "US invests $\$ 165 m$ on Nigeria's agriculture in four years." Agric Base. Aug. I9, 20I9. https://agricbase.com/newsdetails/U_S_ invests_I65m_on_Nigeria_s_agriculture_in _four_years

Ake, Claude. I983. A Political Economy of Africa. London: Longman.

Arieff, Alexis. 2018. "Conflicts in Mali." Congressional Research Service, I9 Sept. 20I8. http://www.fas.org/spg/crs/row/IFiois6.pdf

Aworinde, Tobi. 20I9. "Nigeria's Population Hits 190 Million- Population Commission." The Punch, July 9, 2019. http://www.google.com/ amp/s/punchng.com/nigerias-population-hits-I9o-million-population-commission/amp

Blake, James. 20I9. "Terrorism Threatens a Former Oasis of Stability in West Africa." Foreign Policy, Feb. I, 20I9. http://www.foreignpolicy.com/20I9/02/oI/terrorism-threatens-a-former-oasis-of-stability-in-west-africa-burkina-faso-mali-campaore

Chergui, Smail. 2019. "Terrorism Expanding in Sahel, AU Security Chief warns," The Sun, Feb. I2, 2019. https://www.sunnewsonline.com/ terrorism-expanding-in-sahel-au-security-chief-warns

Ellis, Stephen. I999. The Mask of Anarchy, The Destruction of Liberia and the Religious Dimension of an African Civil War. London; G. Murst.

Ferguson, Niall. 2003. Empire: How Britain made the Modern World. USA: Penguin.

Fieldhouse, D.K. I999. The West and the Third World. Oxford and Malden: Blackwell.

Food and Agriculture Organization (FAO) of the United Nations. 2016. FAO. Aug. I9, 20I6. http://www.fao.org/emergencies/fao-in-action/stories-detail/en/c/429816/

Gann, Lewis H. and Duignan, Peter. 1967. The Burden of Empire: A Reappraisal of Western Colonialism South of the Sahara. Hoover Institution Archives. 
Gberie, Lansana. 20I6. “Terrorism Overshadows Internal Conflicts." Africa Renewal, Apr. 20I6, http://www.un.org/africarenewal/magazine/ april-2016/terrorism-overshadows-internal-conflicts

International Security Sector Advisory Team (ISSAT). 20I9. "Facing the Challenge of the Islamic State in West Africa Province." ISSAT. Aug. I2, 20I9. https://issat.dcaf.ch/fre/Apprendre/La-bibliotheque-des-ressources/Recherches-et-documents-strategiques/Facing-the-Challenge-of-the-Islamic-State-in-West-Africa-province

Kelly, Fergus. 20I9. "ISWAP Killed 'dozens' of Nigeria and Chad troops near Baga in July 29 Clashes." The Defense Post, Aug. I, 2019. http://thedefensepost.com/2019/08/or/nigeria-baga-iswap-borno

Kuerschner, Mareike. 2013. "Conflicts in African States”. I5 Apr. 2013. http:// www.e-ir.info/2013/03/15/conflicts-in-west-african-states /

Lawal, A.A. I997. "The Economy and the State from the Precolonial Times to the Present." In Nigerian Peoples and Cultures, edited by Akinjide Osuntokun \& Ayodeji Olukoju, 210-74. Ibadan: Davidson Press.

McPake, B., Hanson K., \& Mills, A. I993. "Community Financing of Health Care in Africa: An Evaluation of the Bamako Initiative." Social Science and Medicine 36, no. II: 1383-95.

Miles, Donna. 2005. "New Counter terrorism Initiative to Focus on Saharan Africa." US Department of Defense News Article, May I6, 2005. https://web.archive.org/web/20070II5212856/http://www.defenselink.mil/news/May2005/20050516_II26.html

Nossiter, Adam. 20I2. "Jihadists' Fierce Justice Drives Thousands to Flee Mali." The New York Times, July i8, 2012.

Odejide, Olabisi \& Morakinyo, Jide. 2003. "Mental Health and Primary Care in Nigeria." World Psychiatry 2, no. 3 (Oct): $164-65$.

Ogunremi, G.O. and Faluyi, E.K. I996. An Economic History of West Africa since 1750, Ibadan: Rex Charles.

Olagbaju, J. and Falola, Toyin. I996. "Economic Cooperation: The ECOWAS Example." In An Economic History of West Africa since 1750, edited by G.O. Ogunremi and E.K. Faluyi, 225-27, Ibadan: Rex Charles.

Olagbaju, J. and Falola, Toyin. I996. "Post-independence Economic Challenges and Development." In An Economic History of West Africa since 1750, edited by G.O. Ogunremi and E.K. Faluyi, 234-35, Ibadan: Rex Charles. 
Onyekpe, J.G.N. I997. "Western Influence on Nigeria in the Era of 'New Imperialism." In Nigerian Peoples and Cultures, edited by Akinjide Osuntokun \& Ayodeji Olukoju, 220-45. Ibadan: Davidson Press.

Pujol-Mazzini, Anna. 20I8. "Islamist Terrorist Groups are Turning their Attention to West Africa." Washington Post, 3 July 2018, www.washingtonpost.com/news/worldviews/wp/2018/07/03/ islamist-terrorist-groups-are-turning-their-attention-to-west-africa/?noredirect=on\&utm_term=7c5ac7ibdae3

Rodney, Walter. I972. How Europe Underdeveloped Africa. London: Bogle-L'Ouver.ture Publications.

Sahara Reporters. 20I9. "Bandit Commanders Agree To Suspend Attacks in Zamfara." Sahara Reporters. July 20, 2019. http://sharareporters. com/20I9/07/20/bandit-commanders-agree-suspend-attacks-zamfara

Umeh, Kanayo, and Alabi. 20I9. Abdulganiyu. "Foreign Powers Sponsoring Terrorism-Army Alleges.” The Guardian, May 5, 20I9. http://m. guardian.ng/news/foreign-powers-sponsoring-terrorism-army-alleges/

United Nations. 2006. "UN Global Counter-Terrorism Strategy." United Nations. Sept. 8, 2006. https://www.un.org/counterterrorism/ctitf/ en/un-global-counter-terrorism-strategy

Watson, Jack. I984. Success in Twentieth Century World Affairs from 1919 to the 1980s. London: John Murray Publishers Ltd.

WHO Regional Office for Africa. 20I7. "Panel Discussion on the Health Impact of War and Terror: Coordinating Aid: Talking Points of the WHO Regional Director in Africa." World Health Organization. http:// www.afro.who.int/regional-director/speeches-messages/health-impact-war-terror-aid-dr-matshidiso-moeti-talking-points 


\section{ABSTRACT}

This paper attempts a qualitative historical analysis of the nexus between aspects of socio-political challenges and the intensification of terrorism in post-independence Nigeria, Burkina Faso, and Mali. The analysis is especially restricted to terrorist groups such as the Boko Haram and Islamic State West Africa Province (ISWAP). Slight references, however, are, made to other African countries and terrorist groups such as al-Qaeda, ISIS, and their affiliates. It underscores the significance of the aforementioned countries, noting why they are currently recognised in contemporary global discourse as refuge of terrorists in West Africa. It examines the interventionist and collaborative roles played by international and regional entities and initiatives such as the United Nations (UN), G5-Sahel, Multinational Joint Task Force (MNJTF), Trans-Saharan Counterterrorism Initiative (TSCTI), Multidimensional Integrated Stabilization Mission in Mali (MINUSMA), and the Economic Community of West African States (ECOWAS), among others. Using the historical method, which involves the evaluation and analysis of secondary sources, alongside other relevant qualitative evidence, the paper argues that the socio-political challenges faced in these countries, during the late twentieth century, not only served as a catalyst for the twenty-first century emanation and spread of terrorism, but it also compounded or worsened them. It concludes by demonstrating the strategies and prospects for the qualitative development of the sub-region, noting that if the socio-political and economic variables are effectively addressed, terrorism, alongside its ravaging consequences, could be curtailed.

\section{KEYWORDS}

Terrorism; West Africa; Contemporary; Development; Socio-Political; Africa. 